Ege Tıp Dergisi / Ege Journal of Medicine 2018;57(2):107-112

\title{
Küçük hücreli dışı akciğer karsinomlarında tümör ilişkili makrofajların tümör progresyonundaki rolü
}

The role of tumor-associated macrophages on tumor progression in non-small cell lung
$\begin{aligned} & \text { carcinoma } \\ & \text { Merih Tepeoğlu } \quad \text { F.Zeynep Taştepe } \quad \text { B.Handan Özdemir } \\ & \text { Başkent Üniversitesi Ankara Hastanesi, Patoloji Kliniği, Ankara, Türkiye }\end{aligned}$

Öz

Amaç: Akciğer kanseri tüm dünyada kanserden ölümlerin en sık sebebidir. Küçük hücreli dışı akciğer karsinomları (KHDAK) da en sık görülen akciğer kanser tipidir. Bu çalışmada küçük hücreli dışı akciğer karsinomlarında, tümör ilişkili makrofajların (TAM) tümör progresyonu ve metastaz üzerindeki etkileri araştırıldı.

Gereç ve Yöntem: Ocak 2011 ile Mayıs 2016 tarihleri arasında Başkent Üniversitesi Tıp Fakültesi Patoloji Anabilim Dalında KHDAK tanısı alan 80 olgu çalışmaya dahil edildi. Olguların klinik takip bulguları kaydedildi ve tüm olgulara immünhistokimyasal olarak CD 68 antikoru uygulandı.

Bulgular: Olguların 36'sı (\%45) skuamöz hücreli karsinom (SHK), 36'sı (\%45) adenokarsinom, 6'sı (\%7.5) büyük hücreli karsinom ve 2'si de (\%\%2.5) adenoskuamöz karsinom idi. Yapılan immünhistokimyasal çalışma sonucunda, 28 olgunun (\%35) tümör dokusunda 1+, 21 olgunun (\%26.3) tümör dokusunda 2+ ve 31 olgunun (\%38.8) tümör dokusunda ise 3+ TAM yoğunluğu izlendi. Evre 1 olan 32 hastanın yalnızca 1 tanesi (\%3.1) 3+ TAM yoğunluğuna sahipken, evre 2 olan 32 hastanın 17'sinde (\%53.1) ve evre 3+4 olan 16 hastanın ise 13'ünde (\%81.3) 3+ TAM yoğunluğu saptandı. TAM yoğunluğu 1+ olan hastaların ortalama yaşam ömrü $39.7 \pm 17.4$ ay iken, TAM yoğunluğu 2+ olan hastaların $36.6 \pm 17.1$ ay ve TAM yoğunluğu $3+$ olan hastaların ise $27.3 \pm 18.4$ aydı $(p<0.05)$.

Sonuç: Bu çalışmada, patolojik T evresi ve TNM evresi yüksek olan KHDAK'da TAM sayısının daha yüksek olduğu görüldü ve yüksek TAM sayısı olan hastaların ortalama sağkalım süresinin de, düşük TAM sayısı olan hastaların sağkalım süresinden kısa olduğu saptandı.

Anahtar Sözcükler: Akciğer, küçük hücreli dışı akciğer karsinomu, tümör ilişkili makrofaj.

\section{Abstract}

Aim: Lung cancer remains the leading cause of cancer-related mortality in all over the world. Non-small cell lung cancer (NSCLC) is the most frequent type of lung carcinoma. In the current study, the effects of tumor-associated macrophages (TAM) on tumor progression and metastasis in NSCLC were investigated.

Materials and Methods: Eighty NSCLC cases, which were diagnosed in Başkent University Medical School, Department of Pathology between January 2011 and May 2016 were included into the study. Clinical follow-up findings of the patients were recorded and CD68 immunohistochemistry was performed to all of them.

Results: Histologically, 36 cases (45\%) were squamous cell carcinoma, 36 cases (45\%) were adenocarcinoma, 6 cases (7.5\%) were large cell carcinoma, and 2 cases were adenosquamous carcinoma (2.5\%). The density of TAM in tumor tissue was $1+$ in 28 cases (35\%), 2+ in 21 cases (26.3\%) and $3+$ in 31 (38.8\%) cases by immunohistochemistry. In addition, the density of TAM was 3+ in only 1 (3.1\%) of 32 stage 1 patients, 17 (53.1\%) of 32 stage 2 and 13 (81.3\%) of 16 stage 3 and 4 patients had $3+$ TAM density. The average survival was $39.7 \pm 17.4$ months, 36.6 \pm 17.1 months and 27.3 \pm 18.4 months respectively $(p<0.05)$, in the the patients who had $1+, 2+$ and $3+$ TAM density.

Conclusion: In the current study, we detected that the number of TAM is higher in NSCLC patients who had higher pathological T and TNM stage. Also, an average survival of the patients who had a higher number of TAM was shorter than the patients who had a lower number of TAM.

Keywords: Lung, non-small cell lung carcinoma, tumor-associated macrophages. 


\section{Giriş}

Akciğer kanseri tüm dünyada kanserlerden ölümlerin en sık sebebidir (1). Akciğer kanserlerinin yaklaşık \%85'ini küçük hücreli dışı akciğer kanserleri (KHDAK) oluşturmaktadır $(1,2)$. KHDAK'lerinde tüm hastalar içinde sağkalım \%15 iken, opere edilebilir hastalarda bu oran \%50-60'tır $(1,2)$. İnflamatuvar mikro çevrenin tümör gelişimi ve ilerlemesinde etkili olduğu ve bu iki antiteyi birbirine bağlayan durumun, inflamasyonun onkogenleri aktive etmesi ve sonucunda inflamatuvar sürecin kansere yol açması olduğu düşünülmektedir (3). Tümör mikro çevresinde bulunan tümör ilişkili makrofajlar (TAM), salgıladıkları çeşitli büyüme faktörleri, sitokinler, inflamatuvar mediyatörler ve proteolitik enzimler ile tümör progresyonunda rol oynamaktadır. TAM'lar, immünsüpresyon, metastaz, anjiyogenez ve lenfanjiyogenez üzerine etki göstererek tümörün ilerlemesine katkı sağlamaktadır. (4,5). Solid organ tümörleri üzerinde yapılan bazı araştırmalarda, yüksek yoğunlukta TAM içeren tümörlerin daha ileri evrede oldukları ve daha sık metastaz yaptıkları gösterilmiş olup. Küçük hücreli dışı akciğer kanserlerinde ise TAM'ların tümör dokusunda fazla bulunmalarının kötü prognostik faktör olduğunu vurgulayan çeşitli çalışmalar mevcuttur $(6,7)$. Bu çalışmada da, KHDAK'lerinde tümör ilişkili makrofajların (TAM) tümör progresyonu üzerindeki etkisi araştırılmıştır.

\section{Gereç ve Yöntem}

Ocak 2011 ile Mayıs 2016 tarihleri arasında Başkent Üniversitesi Tıp Fakültesi Ankara Hastanesi Patoloji Anabilim Dalında KHDAK tanısı alan ve düzenli klinik takibi olan 80 olgu çalışmaya dahil edildi. Her olgunun dosyasından takip süresi, hayatta kalma süresi ve klinik takip bilgilerine [akciğer grafisi, pozitron emisyon tomografi (PET), ve manyetik rezonans görüntüleme (MR), preoperatif ve postoperatif tedavileri] ulaşıldı. Çalışmaya Hastane Klinik Araştırmalar ve Etik Kurulu onayı alındıktan sonra başlandı.

Her olgunun hemotoksilen\&eozin (H\&E) boyalı preparatlarının tamamı yeniden değerlendirilerek, olguların tümü American Joint Committee on Cancer (AJCC) tarafından 2015 yılında modifiye edilen TNM sistemi ve patolojik evrelendirilmesine göre yeniden evrelendirildi. Skuamöz hücreli karsinom histolojik tipindeki tümörler iyi-orta-az diferansiye ve adenokarsinom histolojik tipindeki tümörler asiner, lepidik, solid, papiller baskın paternlerine göre sınıflandırıldı. Ayrıca ameliyatın şekli, cerrahi sınırların durumu, plevra tutulumu, lenfovasküler invazyon varlığı yeniden değerlendirildi. Lenf nodu diseksiyonu yapılan olgularda lenf nodlarına ait H\&E boyalı preparatların tamamı tekrar incelenerek lenf nodu metastazları yeniden değerlendirildi. Her bir olgu için tümör histolojik tipini en iyi temsil eden ve komşu normal akciğer dokusunu da içeren parafin bloklar seçilerek, immünhistokimyasal olarak kullanıma hazır Cluster of Differentiation 68 (CD68) antikoru (monoklonal, klon KP1, DAKO), DAKO Autostainer Link 48, Denmark cihazında otomatik olarak çalışıldı. CD68 monoklonal antikoru ile tümör içindeki makrofajların varlığı değerlendirildi. CD68 ile boyanan makrofajlar x400 orijinal büyütmede ve en yüksek 3 alanda sayılarak ortalama değerler bulunarak 3 skor altında değerlendirildi; CD68 boyalı makrofaj sayısı 0-5 arasında ise Skor 1, 5-15 arasında ise Skor 2 ve 15'den fazla ise Skor 3 olarak gruplandırıldı.

Verilerin istatiksel analizleri Statistical Package for the Social Sciences (SPSS) for Windows yazılımı, version 15.0, SPSS Inc, Chicago, IL, USA ile yapıldı. Klinikopatolojik verilerin immünohistokimyasal veriler ile karşılaştırılmasında Ki-kare testi, Mann-Whitney $U$ testi (iki grup arasındaki karşılaştırma) ve Kruskal Wallis testi (ikiden fazla grup arasındaki karşılaştırma) kullanıldı. Kantitatif değişkenler için değerler ortalama \pm standart sapma olarak verildi. ' $p$ ' değeri 0,05 'in altındaki değerler istatiksel olarak anlamlı kabul edildi. Hastaların sağkalım hızları Kaplan-Meier sağkalım analizi kullanılarak verildi.

\section{Bulgular}

Çalışmamızda incelenen KHDAK'li 80 hastanın 9'u (\%11.3) kadın ve 71'i (\%88.8) erkekti. Hastaların ortalama yaşları $63.46 \pm 9.19$ (37-47) olup, hastalar ortalama $34.3 \pm 18.2(1-70)$ ay süre ile takip edildi. Hastaların 49'u (\%61.2) halen yaşamakta iken, 31 hasta

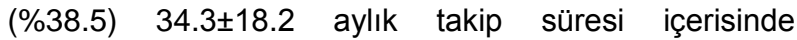
kaybedildi. Hastaların 15'i (\%18.84) operasyon öncesi neoadjuvan kemoterapi (KT) almıştı. Operasyon sonucu incelenen materyallerde, 80 hastanın 36'sında (\%45) skuamöz hücreli karsinom (SHK), 36'sında (\%45) adenokarsinom, 6'sında (\%7.5) büyük hücreli karsinom ve 2'sinde (\% $\% 2.5)$ adenoskuamöz karsinom saptandı. SHK tanısı alan 36 hastanın 6'sı (\%16.7) iyi diferansiye, 24'ü (\%66.7) orta derece diferansiye ve 6'sı (\%16.7) az diferansiye idi (Şekil-1). Adenokarsinom tanısı alan 36 hastanın ise $21 ' \mathrm{i}$ (\%58.3) asiner, 9'u (\%25) solid, 2'si (\%5.5) papiller, 2'si (\%5.5) lepidik ve 1'i (\%2.7) mikropapiller paternde idi. Olguların klinik parametreleri Tablo-1'de gösterilmiştir.

Klinik parametreler kendi aralarında değerlendirildiğinde, tümörün histolojik tipi ile hastaların patolojik $T$ evreleri arasında istatiksel olarak anlamlı farklılık izlendi $(p<0.05)$. Skuamöz hücreli karsinomlu hastaların \%33'ü erken T evresine (pT1) sahipken, \%16.7'si ileri T evresindeydi (pT2b ve T3). Buna karşılık non-skuamöz hücreli karsinomlu hastaların (adenokarsinom ve büyük hücreli karsinom) ise \%43'ünün erken $T$ evresinde ve \%34.1'inin ileri $\mathrm{T}$ evresinde oldukları görüldü. Benzer şekilde, tümörün histolojik tipi ile hastaların klinik evreleri arasında da istatiksel olarak anlamlı fark saptandı $(p<0.05)$. Skuamöz hücreli tümörler, non-skuamöz 
hücreli tümörlere göre daha yüksek klinik TNM evresine sahip idi $(p<0.05)$. Ayrıca hastaların patolojik T evresi ile tedavi sonrası nüks/metastaz gelişimi arasında da istatiksel olarak anlamlı pozitif ilişki bulundu $(p=0.05)$. Buna göre ileri $T$ evresindeki hastalarda, erken $T$ evresindeki hastalar ile karşılaştırıldıklarında, tedavi sonrasında daha yüksek oranda nüks/metastaz görüldüğü tespit edildi. Benzer şekilde klinik evresi yüksek olan hastalarda daha sık oranda metastaz gelişimi olduğu görüldü $(p<0.05)$.

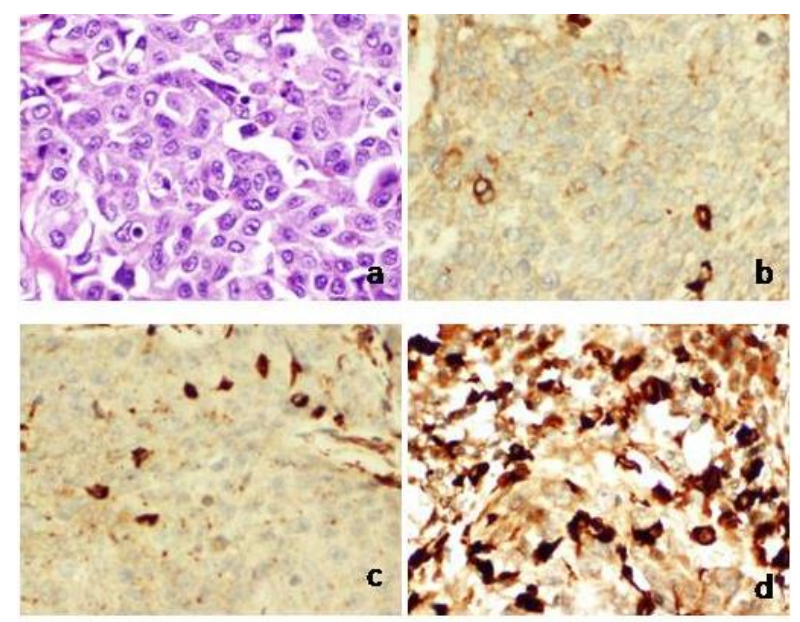

Şekil-1. a. Histopatolojik olarak geniş eozinofilik sitoplazmalı, belirgin nükleollü iri hücrelerden oluşan az diferansiye bir skuamöz hücreli karsinom olgusu izleniyor (hematoksilen\&eozin, $\quad$ x400). b,c,d. Olgunun immünhistokimyasal olarak CD68 antikoru ile farklı tümör alanlarında izlenen skor 1 (b), skor 2 (c) ve skor 3 (d) TAM boyanma yoğunluğu görülüyor (CD68, $\mathrm{x} 400)$.
Yapılan immünhistokimyasal çalışma sonucunda, KHDAK tanısı almış 80 hastanın 28'inin (\%35) tümör dokusunda 1+, 21 'inin (\%26.3) tümör dokusunda $2+$ ve 31 'inin (\%38.8) tümör dokusunda ise 3+ TAM yoğunluğu izlendi (Şekil-1). Hastaların TAM yoğunluğu ile klinikopatolojik parametreleri arasındaki ilişki Tablo-2'de gösterilmiştir. TAM yoğunluğu $1+$ olan hastaların ortalama yaşam ömrü $39.7 \pm 17.4$ ay iken, TAM yoğunluğu $2+$ olan hastaların $36.6 \pm 17.1$ ay ve TAM yoğunluğu $3+$ olan hastaların ise $27.3 \pm 18.4$ aydı. Tümördeki TAM yoğunluğu arttıkça, ortalama yaşam ömrünün anlamlı şekilde kısaldığı görüldü $(p<0.05)$. Benzer şekilde TAM ile patolojik T evresi $(p<0.05)$, lenf nodu metastazı $(p<0.001)$ ve TNM klinik evresi $(p<0.001)$ arasında da istatistiksel olarak anlamlı ilişki saptandı. Neoadjuvan KT alan 15 hastanın 4'ünde (\%26.7) 1+ TAM yoğunluğu, 4'ünde (\%26.7) 2+ TAM yoğunluğu, 7 tanesinde (\%46.6) ise 3+ TAM yoğunluğu saptanmış olup, istatistiksel olarak neoadjuvan KT ile TAM yoğunluğu arasında anlamlı ilişki görülmedi ( $p>0.05)$.

Takip süresi içinde ölen 31 hastanın 7'sinde 1+, 9'unda $2+$ ve 15 tanesinde de 3+ TAM yoğunluğu saptanmış, yaşayan 49 hastanın ise 21 'inde $1+, 12$ 'sinde $2+$ ve 16 'sında da 3+ TAM yoğunluğu görüldü. Bu bulgularla istatistiksel olarak ölen/yaşayan hastalar ile TAM yoğunluğu arasında anlamlı ilişki görülmüş olup, kanserden ölen hastalardaki TAM sayısı, yaşayan hastalardaki TAM sayısına göre daha yüksek bulundu $(p>0.05)$. (Tablo-2).

Tablo-1.Küçük Hücreli Dışı Akciğer kanseri Tanısı Almış 80 Hastanın Klinik Parametreleri.

\begin{tabular}{|c|c|c|}
\hline Klinik Parametre & & n (\%) \\
\hline Kadın & & $9(\% 11.3)$ \\
\hline Erkek & & $71(\% 88.8)$ \\
\hline \multirow{2}{*}{ Neoadjuvan kemoterapi } & Var & $15(\% 18.8)$ \\
\hline & Yok & $65(\% 81.3)$ \\
\hline \multirow{4}{*}{ Histolojik tip } & Skuamöz hücreli karsinom & $36(\% 45.0)$ \\
\hline & Adenokarsinom & $36(\% 45.0)$ \\
\hline & Büyük hücreli karsinom & $6(\% 7.5)$ \\
\hline & Adenoskuamöz karsinom & $2(2.5)$ \\
\hline \multirow{3}{*}{ Patolojik T evresi } & 1 & $31(\% 38.8)$ \\
\hline & 2 & 37 (46.3) \\
\hline & 3 & $12(\% 15.0)$ \\
\hline \multirow{3}{*}{ Lenf nodu metastaz varlığı } & 0 & $48(\% 60.0)$ \\
\hline & 1 & $21(\% 26.3)$ \\
\hline & 2 & $11(\% 13.8)$ \\
\hline \multirow{2}{*}{ Uzak organ Metastazı varlığı } & Yok & $78(\% 97.5)$ \\
\hline & Var & $2(\% 2.5)$ \\
\hline \multirow{6}{*}{ Klinikopatolojik evre } & $1 \mathrm{a}$ & $22(\% 27.5)$ \\
\hline & $1 b$ & $10(\% 12.5)$ \\
\hline & $2 a$ & $20(\% 25.0)$ \\
\hline & $2 b$ & $12(\% 15.0)$ \\
\hline & $3 a$ & $14(\% 17.5)$ \\
\hline & 4 & $2(\% 2.5)$ \\
\hline
\end{tabular}


Tablo-2. Hastaların Klinik Parametreleri ve Tümördeki TAM Yoğunluğu Arasındaki İlişki.

\begin{tabular}{|c|c|c|c|c|c|c|}
\hline & & \multicolumn{3}{|c|}{ TAM yoğunluğu } & \multirow[b]{2}{*}{ Toplam } & \multirow[b]{2}{*}{$\mathbf{p}$} \\
\hline & & $\begin{array}{c}1+ \\
(n, \%)\end{array}$ & $\begin{array}{c}2+ \\
(\mathrm{n}, \%) \\
\end{array}$ & $\begin{array}{c}3+ \\
(n, \%)\end{array}$ & & \\
\hline \multirow{4}{*}{ Histolojik tip } & SHK & $14(\% 38.9)$ & $8(\% 22.2)$ & $14(\% 38.9)$ & 36 & \multirow{4}{*}{$>0.05$} \\
\hline & AK & $13(\% 36.1)$ & $11(\% 30.6)$ & $12(\% 33.3)$ & 36 & \\
\hline & BHK & $1(\% 16.7)$ & $1(\% 16.7)$ & $4(\% 66.7)$ & 6 & \\
\hline & ASK & $0(-)$ & $1(\% 50)$ & $1(\% 50)$ & 2 & \\
\hline \multirow{3}{*}{ Patolojik T evresi } & T1 & $15(\% 48.4)$ & $10(\% 32.3)$ & $6(\% 19.4)$ & 31 & \multirow{3}{*}{$<0.05$} \\
\hline & T2 & $10(\% 27)$ & $7(\% 18.9)$ & $20(\% 54.1)$ & 37 & \\
\hline & T3 & $3(\% 35)$ & $4(\% 26.3)$ & $5(\% 38.8)$ & 12 & \\
\hline \multirow{2}{*}{ Lenf nodu metastazı (N) } & Yok & $26(\% 54.2)$ & $14(\% 29.2)$ & $8(\% 16.7)$ & 48 & \multirow{2}{*}{$<0.001$} \\
\hline & Var & $2(\% 6.3)$ & $7(\% 21.9)$ & $23(\% 71.9)$ & 32 & \\
\hline \multirow{4}{*}{ Klinik evre (TNM) } & 1 & $20(\% 62.5)$ & $11(\% 34.4)$ & $1(\% 3.1)$ & 32 & \multirow{4}{*}{$<0.001$} \\
\hline & 2 & 7 (\%21.9) & 8 (\%25) & $17(\% 53.1)$ & 32 & \\
\hline & 3 & $0(-)$ & $2(\% 14.3)$ & $12(\% 85.7)$ & 14 & \\
\hline & 4 & $1(\% 50)$ & $0(-)$ & $1(\% 50)$ & 2 & \\
\hline \multirow{2}{*}{$\begin{array}{c}\text { Vasküler invazyon } \\
\text { varlığı }\end{array}$} & Yok & $16(\% 41)$ & $11(\% 28.2)$ & $12(\% 30.8)$ & 29 & \multirow{2}{*}{$>0.05$} \\
\hline & Var & $12(\% 29.3)$ & $10(\% 24.4)$ & 19 (\%46.3) & 41 & \\
\hline \multirow{2}{*}{$\begin{array}{c}\text { Tedavi sonrası } \\
\text { Metastaz gelişimi }\end{array}$} & Yok & 24 (\%36.9) & $19(\% 29.2)$ & 22 (\%33.8) & 65 & \multirow{2}{*}{$>0.05$} \\
\hline & Var & $4(\% 26.7)$ & $2(\% 13.3)$ & $9(\% 60)$ & 15 & \\
\hline \multirow{2}{*}{$\begin{array}{l}\text { Tedavi sonrası } \\
\text { Nüks gelişimi }\end{array}$} & Yok & $28(\% 37.8)$ & 17 (\%23) & 29 (\%39.2) & 74 & \multirow{2}{*}{$>0.05$} \\
\hline & Var & $0(-)$ & $4(\% 66.7)$ & 2 (\%33.3) & 6 & \\
\hline \multirow{2}{*}{ Yaşam durumu } & Yaşıyor & $21(\% 42.9)$ & $12(\% 24.5)$ & $16(\% 32.6)$ & 49 & \multirow{2}{*}{$<0.05$} \\
\hline & ÖImüş & $7(\% 22.6)$ & 9 (\%29) & $15(\% 48.4)$ & 31 & \\
\hline
\end{tabular}

TAM: Tümör ilişkili makrofaj, SHK: Skuamöz hücreli karsinom, AK: Adenokarsinom, BHK: Büyük hücreli karsinom, ASK: Adenoskuamöz karsinom.

\section{Tartışma}

Akciğer kanseri her iki cinsiyette de en sık ölüme sebep olan kanser tipidir (1). Küçük hücreli dışı akciğer karsinomları da, akciğer kanserleri içerisinde en sık görülen (\%85) tümörlerdir (2).

KHDAK'lerinin tedavisi cerrahi, radyoterapi ve kemoterapi olup, hastaların büyük oranda ileri evrede tanı almaları sebebiyle sağkalımları oldukça kısadır (13). Son yıllarda hastaların prognozlarını ve sağkalımlarını belirlemeye yönelik çalışmalar yapılmaktadır. Bu araştırmaların bazıları inflamasyon ile kanser arasında ilişki olduğunu göstermektedir (4-10). İnflamatuvar mikro çevrenin tümör gelişimi ve ilerlemesinde etkili olduğu bilinmektedir. İnflamasyon ilişkili programın onkogenleri aktive ettiği ve bunun sonucunda inflamatuvar durumun kansere yol açtığı düşünülmektedir (4-10). Bu yolda ise transkripsiyon faktörleri, TGF-ß gibi sitokinler ve kemokinler rol almaktadır (4). Normalde tümörü infiltre eden immün hücrelerin büyük kısmını tümörü infiltre eden lenfositler (TIL) oluşturur. Geri kalanı ise tümör ilişkili makrofajlar (TAM), dendritik hücreler ve granülositlerden ibarettir. Tümör mikro çevresindeki bu hücrelerin bir kısmı immün aktivasyonu desteklerken, diğer kısmı inflamasyonu baskılama yönünde çalışırlar.

Makrofajlar kanda dolaşan monositlerden köken almaktadır. TGF-ß, monositlerin makrofaja diferansiye olmalarında etkilidir (4). Makrofajlar heterojenik davranışlar gösterip, içlerinde bulundukları mikro çevrelerine uyum sağlamak için fenotiplerini değiştirebilirler (makrofaj polarizasyonu) ve böylece dokularda M1 ve M2 olmak üzere 2 farklı makrofaj tipine diferansiye olabilirler (5). M1 makrofajlar, lipopolisakkarit ve gama interferon (IFNY) gibi klasik aktivatörler ile aktive olarak bakterisidal ve antijen-sunucu hücre olarak görev yapıp, naif CD4+ $T$ hücrelerinin Th1 efektör hücreler ve Th17 hücrelerine farklılaşmasını düzenlerler. Bunun aksine M2 makrofajlar ise alternatif yoldan IL-4, IL-10, IL-13 tarafından aktive olurlar ve CD4+ Th2 hücreleri ve T-reg farklılaşmasını düzenlerler. Böylece M2 makrofajlar B hücrelerinden antikor sentezlenmesini etkinleştirirken, sitotoksik $\mathrm{CD} 8+\mathrm{T}$ hücrelerini ise baskılarlar. Bunun sonucunda ise mikro çevredeki CD4+/CD8+ T lenfosit oranında artmaya sebep olurlar (5). Tümör mikro çevresinde bulunan TAM'lar ise M2 fenotipinde makrofajlardır. Tümörde TAM'ların artışını sağlayan, tümör hücrelerinden salgılanan colonystimulating factor-1 (CSF-1), chemocine ligand (CCL) 23-4-5-8, vasküler endotelyal büyüme faktörü (VEGF), makrofaj inflamatuvar protein-1 alfa (MIP-1 $\alpha$ ), makrofaj migrasyon inhibitor faktör (MIF) gibi monosit kemoatraktanlarıdır. Tümör mikro çevresinde bulunan TAM'lardan salgılanan çeşitli büyüme faktörleri, sitokinler, inflamatuvar mediyatörler ve proteolitik enzimler, tümör progresyonunda etkili olan immünsupresyon, metastaz, anjiyogenez ve lenfanjiyogenezde oldukça etkilidir $(4,5)$. 
TAM'lar anjiyogenez üzerine etkisini, tümör kitlesindeki düşük oksijen basıncı ya da hipoksi sonucu salınan inflamatuvar moleküllerin etkisi ile ortama gelmeleri ve VEGF, fosforilaz ve ürokinaz plazminojen aktivatör gibi birçok anjiogenik faktörler salgılaması ve bu moleküllerin de endotel hücrelerinin çoğalmasını, migrasyonunu ve yeni damarlara farklılaşmasını sağlaması ile gerçekleştirir. (5). Yine TAM'lardan salınan temel fibroblast büyüme faktörü (bFGF), epidermal büyüme faktörü (EGF), transforming büyüme faktörü (TGF a ve ß) de tümör hücrelerinde büyümeyi tetikler ve endotelde stimülasyona neden olarak tümör vaskülaritesini arttırır (5).

TAM'lar ayrıca çeşitli immünmodulatör sitokinler ve büyüme faktörleri salgılayarak, konağın tümöre karşı olan immün yanıtını azaltıllar. Salgıladıkları bu maddeler ile sitotoksik $T$ hücreler gibi anti-tümörojenik hücrelerin ortama gelmesini engeller, CCL17 ve CCL22 kemokin salgısı ile de T-reg ve Th2 hücreler gibi immün yanıtı baskılayan hücrelerin ortama ulaşmasına katkıda bulunurlar ve diğer antijen sunan hücrelerde downregulasyona sebep olurlar. Lenfanjiyogenez üzerine etkisini de, özelleşmiş endotel hücrelerinden lenfatiklerin oluşmasını başlatan VEGF-C ve VEFG-D gibi büyüme faktörlerini salgılayarak gerçekleştirirler (5).

Literatürde yapılan çalışmalarda, çeşitli organ tümörlerinde yüksek sayıda TAM varlığının kötü prognoz ve metastaz ile ilişkili olduğu gösterilmiştir. Kolon kanserinde TAM sayısının artmasıyla tümörün evre ve histolojik derecesinin arttığı gösterilmiş olup karaciğer metastaz riskinin de yüksek olduğu bildirilmiştir $(9,10)$. Ayrıca epitelyal over karsinomlarında da TAM yoğunluğunun histolojik derece ile ilişkili olduğu bulunmuştur (11). Özofagus skuamöz hücreli karsinomda (12), mesane kanserinde (13), malign melanomda (14) TAM yoğunluğunun yüksek olduğu olgularda tümör invazyonunun fazla olduğu bildirilmiştir. Zhang ve ark. $(15,16)$ yaptığı bir çalışmada ise, yüksek TAM sayısının mide, ürogenital ve baş-boyun karsinomlarında kötü prognoz ve yaşam ömrü ile ilişkili olduğu bulunurken, kolorektal kanserli hastalarda ise iyi prognoz ile ilişkili olduğu gösterilmiştir.

KHDAK'li hastalarda yapılan birçok çalışmada ise TAM yoğunluğunun kötü prognoz ile ilişkili olduğu gösterilirken bunun tersini söyleyen yayınlar da vardır. Zhang ve ark. $(15,16)$, akciğer adenokarsinomlarında TAM yoğunluğunun lenfanjiyogenezi arttırarak lenf nodu metastazına yol açtıkları ve bundan dolayı da kötü prognoz ile ilişkili olabileceğini vurgulamıştır. Çalışmamızda da benzer şekilde lenf nodu metastazı olan hastalarda TAM yoğunluğunun yüksek olduğu saptanmıştır. Arenberg ve ark. (17) KHDAK'li olgularda yaptığı çalışmada, kanserden ölen hastalardaki TAM sayısı, yaşayan hastalar ile karşılaştırıldığında anlamlı olarak yüksek bulunmuştur. Benzer şekilde Chen ve ark. (18) da yüksek TAM sayısı olan hastalardaki ortalama yaşam ömrünün, düşük TAM sayısı olan hastalardan belirgin olarak kısa olduğunu göstermişlerdir. Bizim çalışmamızda da benzer olarak yüksek TAM sayısı olan hastaların, düşük TAM sayısı olanlara göre ortalama yaşam süreleri kısa bulunmuştur. Ayrıca kanserden ölen hastalardaki TAM sayısı da, yaşayan hastalardaki TAM sayısına göre belirgin olarak yüksek saptanmıştır.

Ancak bu bulguların aksine, da Costa Souza ve ark. (19) ise opere olmuş KHDAK'li olgulara ait dokular ile yaptıkları çalışmada, hastalardaki 5 yıllık yaşam ömrünün yüksek makrofaj yoğunluğu ile pozitif olarak korele olduğunu göstermişlerdir (19). Benzer olarak Kim ve ark. (20) da retrospektif olarak yaptıkları ve 144 KHDAK'li olguyu inceledikleri çalışmalarında tümördeki yüksek TAM sayısı olan hastaların, düşük TAM sayısına sahip hastalardan anlamlı olarak daha uzun yaşadıklarını bulmuşlardır. Öte yandan literatürdeki bazı çalışmalarda ise, TAM ile hastaların sağkalımı üzerinde herhangi bir ilişki bulunmamıştır $(21,22)$.

TAM sayısının prognoza etkisinin incelendiği olgularda farklı sonuç ilişkileri görülmesinin muhtemel sebepleri TAM lokalizasyonu (tümör adası ve tümör stroması) ve M1 ve M2 makrofaj fenotiplerinin ayrı ayrı sayılmıyor olmaları olabilir.

\section{Sonuç}

Bu çalışmada, patolojik T evresi ve TNM evresi yüksek olan tümörlerde TAM sayısının daha yüksek olduğu ve bu bulgunun da istatiksel olarak anlamlı olduğunu saptadık. Ayrıca lenf nodu metastazı görülen olgularda da TAM sayısı belirgin olarak yüksek saptandı. Bununla birlikte düşük TAM sayısı olan hastaların ortalama sağkalım süresinin de, yüksek TAM sayısı olan hastaların sağkalım süresinden uzun olduğu görüldü. Kanserden ölen hastalardaki TAM sayısı da, yaşayan hastalardaki TAM sayısından belirgin olarak yüksek saptandı. Öte yandan tedavi sonrası nüks veya metastaz gelişimi ile tümörü infiltre eden TAM sayısı arasında anlamlı bir ilişki saptanmadı. Bulgularımızı literatür eşliğinde değerlendirdiğimizde; küçük hücreli dışı akciğer karsinomlarında tümörü infiltre eden TAM sayısının kötü prognoz ve düşük yaşam ömrü ile ilişkili olduğunu söyleyebiliriz. 


\section{Kaynaklar}

1. Travis DW, Brambilla E, Burke AP, Marx A, Nicholson AG. WHO Classification of Tumours of the Lung, Pleura, Thymus and Heart. 4th ed. IARCPress; Lyon;2015:9-26.

2. Siegel RL, Miller KD, Jemal A. Cancer statistics 2015. CA Cancer J Clin 2015;65(1):5-29.

3. Rothschild SI. Targeted therapies in non-small cell lung cancer-beyond EGFR and ALK. Cancers 2015;7(2):930-49.

4. Mantovani A, Sica A. Macrophages innate immunity and cancer: Balance, tolerance, and diversity. Curr Opin Immunol 2010;22(2):231-7.

5. Coffelt SB, Hughes R, Lewis CE. Tumor-associated macrophages; effectors of angiogenesis and tumor progression. Biochim Biophys Acta 2009;1796(1):11-8.

6. Noy R, Pollard JW. Tumor-associated macrophages: From mechanisms to therapy. Immunity 2014;41(1):49-61.

7. Becker M, Müller CB, De Bastiani MA, Klannt F. The prognostic impact of tumor-associated macrophages and intra-tumoral apoptosis in non-small cell lung cancer. Histol Histopathol 2014;29(1): 21-31.

8. Solinas G, Germano G, Mantovani A, Allavena P. Tumor-associated macrophages (TAM) as major players of the cancer-related inflammation. J Leukoc Biol 2009;86(5):1065-73.

9. Forssell J, Oberg A, Henriksson ML, Stenling R, Jun A, Palmqvist R. High macrophage infiltration along the tumor front correlates with improved survival in colon cancer. Clin Cancer Res 2007;13(5):1472-9.

10. Zhou $Q$, Peng RQ, Wu XJ, et al. The density of macrophages in the invasive front is inversely correlated to liver metastasis in colon cancer. J Transl Med 2010;8(13):1-9.

11. Wan T, Liu JH, Zheng LM, Cai MY, Ding T. Prognostic significance of tumor associated macrophage infiltration in advanced epithelial ovarian carcinoma. Chin J Cancer 2009;28(3):323-7.

12. Liu J, Li Z, Cui J, Xu G, Cui G. Cellular changes in the tumor microenvironment of human esophageal squamous cell carcinomas. Tumour Biol 2012;33(2):495-505.

13. Hanada T, Nakagawa M, Emoto A, Nomura T, Nasu N, Nomura Y. Prognostic value of tumor-associated macrophage count in human bladder cancer. Int J Urol 2000;7(7):263-9.

14. Torisu $\mathrm{H}$, Ono $\mathrm{M}$, Kiryu $\mathrm{H}$, et al. Macrophage infiltration correlates with tumor stage and angiogenesis in human malignant melanoma: possible involvement of TNF alpha and IL-1 alpha. Int J Cancer 2000;85(2):182-8.

15. Zhang QW, Liu L, Gong CY, et al. Prognostic significance of tumor associated macrophages in solid tumor: A meta-analysis of the literature. PLoS One 2012;7(12):1-14.

16. Zhang B, Yao G, Zhang Y, et al. M2-Polarized tumor associated macrophages are associated with poor prognoses resulting from accelerated lymphangiogenesis in lung adenocarcinoma. Clinics 2011;66(11):1879-86.

17. Arenberg DA, Keane MP, DiGiovine $B$, et al. Macrophage infiltration in human non-small-cell lung cancer: the role of $\mathrm{CC}$ chemokines. Cancer Immunol Immunother 2000;49(2):63-70.

18. Chen JJ, Yao PL, Yuan A, et al. Up-Regulation of tumor interleukin-8 expression by infiltrating macrophages its correlation with tumor angiogenesis and patient survival in non-small cell lung cancer. Clin Cancer Res 2003;9(2):729-37.

19. da Costa Souza P, Parra ER, Atanazio MJ, et al. Different morphology, stage and treatment affect immune cell infiltration and long-term outcome in patients with non-small-cell lung carcinoma. Histopathology 2012;61(4):487-596.

20. Kim D, Min H, Lee K, et al. High tumour islet macrophage infiltration correlates with improved patient survival but not with EGFR mutations, gene copy number or protein expression in resected non-small cell lung cancer. Br J Cancer 2008;98(6):1118-24.

21. Toomey D, Smyth G, Condron C, et al. Infiltrating immune cells, but not tumour cells, Express FasL in non-small cell lung cancer: No association with prognosis identified in 3-year follow-up. Int J Cancer 2003;103(3):408-12.

22. Liss C, Fekete MJ, Hasina R, Lam CD, Lingen MW. Paracrine angiogenic loop between head-and-neck squamous-cell carcinomas and macrophages. Int J Cancer 2001;93(6):781-5. 